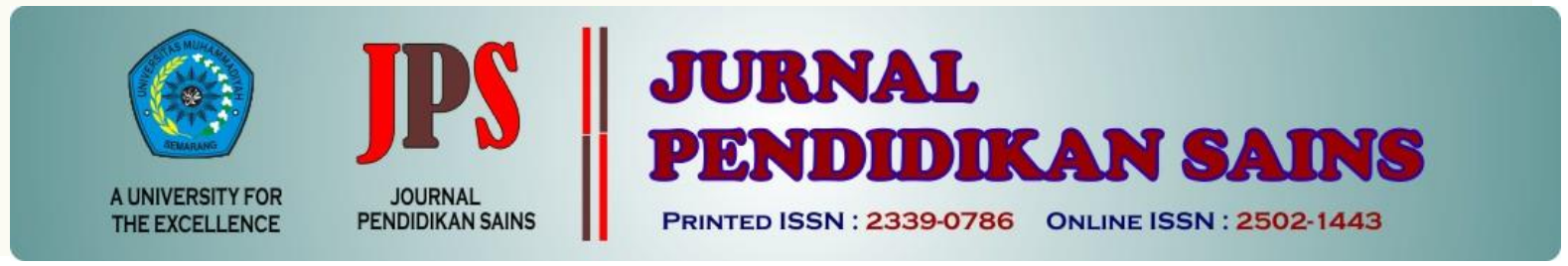

http://jurnal.unimus.ac.id/index.php/JPKIMIA

\title{
PENGARUH MEDIA PEMBELAJARAN MEC BOND TERHADAP KETERAMPILAN BERPIKIR KRITIS DAN HASIL BELAJAR
}

\author{
Nilam Nur Amalia ${ }^{1}$, Agus Kamaludin ${ }^{2}$ \\ ${ }^{1}$ Mahasiswa Pendidikan Kimia, ${ }^{2}$ Dosen Pendidikan Kimia \\ Universitas Islam Negeri Sunan Kalijaga Yogyakarta
}

\begin{tabular}{ll}
\hline \multicolumn{2}{l}{ Article history } \\
\hline Submission & $: 2018-10-04$ \\
Revised & $: 2019-01-24$ \\
Accepted & $: 2019-03-22$
\end{tabular}

Keyword:

Kata kunci: keterampilan berpikir kritis, hasil belajar, media pembelajaran MEc Bond

\begin{abstract}
The purpose of this research was to examine the effect of using MEc Bond learning media on critical thinking skills and students' learning outcomes on chemical bonding material. The research was conducted in State Senior High School 5 Yogyakarta, on $10^{\text {th }}$ grade of mathematics and natural sciences, in the academic year of 2017/2018. The type of research was quasi-experiment with the research design of Non-equivalent Control Group Design. The sampling technique was a simple random sampling. The data collection instruments included pretest until post-test, critical thinking skill test, observation sheet, and questionnaire sheet. The research also carried out an analysis of the stages of students' critical thinking skill, those are clarification, assessment, inference, and strategy. Based on statistical tests, the results showed that the use of MEc Bond learning media had an effect on students' critical thinking skills. However, it did not affect students' learning outcomes. Even so, both the experimental class and the control class showed that the students' learning outcomes was above the average of completeness criteria 70 .
\end{abstract}

\section{Pendahuluan}

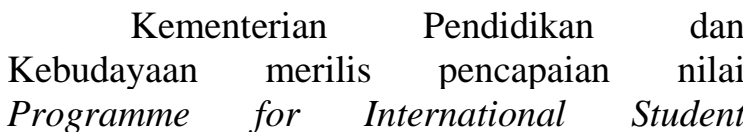
Assessment (PISA) tahun 2015 menyatakan bahwa kondisi saat ini kemampuan siswa Indonesia di bidang sains berada pada peringkat 62 dari 70 negara peserta survei PISA(www.kemendikbud.go.id). Menurut Hayat dan Suhendra (2010: 325) menyatakan bahwa tingkat literasi sains pada PISA siswa di Indonesia umumnya dinilai hanya mampu

*Corresponding Author:

$\begin{array}{ll}\text { Nama } & \text { : Nilam Nur Amalia } \\ \text { Lembaga } & \text { : UIN Sunan Kalijaga Yogyakarta } \\ \text { Email } & \text { : nilam.nuramalia12@gmail.com }\end{array}$

mengingat fakta, istilah, dan hukum-hukum ilmiah serta menggunakannya dalam menarik kesimpulan ilmiah yang sederhana maupun dalam kehidupan sehari-hari. Hasil PISA bidang literasi sains anak Indonesia yang dianalisis Tim Literasi Sains Puspendik tahun 2004 diantaranya mengungkapkan bahwa komposisi jawaban siswa mengindikasikan lemahnya pemahaman siswa terhadap konsepkonsep dasar sains yang sebetulnya telah diajarkan, ketelitian siswa membaca masih rendah, siswa tidak terbiasa menghubungkan informasi-informasi dalam teks untuk dapat 
menjawab soal, dan kemampuan penalaran ilmiah siswa masih rendah (Mahyuddin, 2007). Hal tersebut menunjukkan bahwa siswa di Indonesia masih kesulitan dalam mengasah kemampuan berpikir tingkat tinggi untuk menjawab permasalahan yang memerlukan penalaran. Oleh sebab itu, paradigma pembelajaran sudah seharusnya bergeser dari pembelajaran konvensional yang menekankan pada keterampilan berpikir tingkat rendah ke arah pembelajaran yang menekankan pada keterampilan berpikir tingkat tinggi, terutama kemampuan berpikir kritis (Lubezky dkk, 2004: 184). Seseorang yang berpikir kritis adalah seseorang yang mampu menyelesaikan masalah, membuat keputusan, dan belajar konsep-konsep baru melalui kemampuan bernalar dan berpikir reflektif berdasarkan suatu bukti dan logika yang diyakini benar (Ibrahim, 2011: 125). Adanya pembelajaran yang menekankan pada penyelesaian masalah dapat meningkatkan kemampuan berpikir kritis siswa (Widyaningtyas, Kusumah, Sumarno \& Sabandar, 2015)

Tuntutan akan berpikir kritis juga tercantum dalam ayat-ayat Al Qur'an mengenai bagaimana seseorang dalam berpikir tingkat tinggi bukan berpikir biasa. Seperti halnya pada Q.S. Ali 'Imran: 190-191 yang artinya:

"Sesungguhnya dalam penciptaan langit dan bumi, dan pergantian malam dan siang terdapat tanda-tanda (kebesaran Allah) bagi orang-orang yang berakal, (yaitu) orang-orang yang mengingat Allah, sambil berdiri, duduk, atau dalam keadaan berbaring, dan mereka memikirkan tentang penciptaan langit dan bumi (seraya berkata), Ya Tuhan kami, tidaklah Engkau menciptakan semua ini sia-sia; Maha Suci Engkau, lindungilah kami dari azab neraka".

Ayat tersebut menunjukkan betapa pentingnya seseorang dalam menggunakan kemampuan berpikir yang telah diberikan Tuhan Yang Maha Esa dengan sebaik-baik mungkin. Pada hakikatnya, keterampilan berpikir tingkat tinggi khususnya berpikir kritis dapat dibentuk dengan cara memberikan stimulus yang dapat merangsang siswa untuk berpikir dan bernalar, khususnya dalam pembelajaran.

Berdasarkan hasil wawancara yang telah dilakukan dengan beberapa guru kimia SMA/MA menyatakan bahwa kimia merupakan salah satu materi pembelajaran yang memerlukan daya nalar yang tinggi.
Kemampuan dalam memahami konsep-konsep kimia yang bersifat abstrak menjadi salah satu kesulitan tersendiri bagi siswa karena apabila siswa kurang mampu dalam memahami konsep, maka untuk mencapai keterampilan berpikir kritis juga akan sulit. Hal ini juga dibuktikan dengan hasil observasi terhadap nilai belajar kimia siswa SMA N 5 Yogyakarta yang tergolong masih rendah (di bawah rata-rata KKM).

Salah satu materi pelajaran kimia yang bersifat abstrak dan membutuhkan daya nalar yang tinggi yaitu ikatan kimia. Umumnya, konsep-konsep yang terdapat pada ikatan kimia berupa konsep-konsep yang abstrak dan dilambangkan dengan simbol dalam penjelasan materinya (Kurniawati, W.Y. 2013: 440). Pada ikatan kimia, siswa mengalami kesulitan terutama dalam hal menentukan senyawa yang memiliki ikatan ion, rumus senyawa yang terbentuk dan jenis ikatannya, senyawa yang tidak memenuhi kaidah oktet, senyawa polar, pasangan unsur yang dapat membentuk ikatan ion dan ikatan kovalen (Haris, M. \& Loka, 2013: 31). Oleh sebab itu, perlu adanya upaya dari guru untuk menggunakan suatu media pembelajaran yang dapat membantu siswa dalam mempelajari konsep-konsep ikatan kimia yang abstrak ke arah gambaran visualisasi konsep-konsep ikatan kimia menjadi lebih nyata dan mudah untuk dipelajari.

Salah satu alternatif media pembelajaran yang dapat digunakan dalam materi ikatan kimia adalah media MEc Bond. Media MEc Bond merupakan media berbentuk tiga dimensi yang terdiri dari papan, elektronelektron dan beberapa lambang unsur kimia tertentu yang dilengkapi dengan magnet. Cara penggunaan media MEc Bond adalah dengan menempelkan lambang unsur kimia beserta elektron-elektronnya pada papan magnet. Adapun karakteristik dari media MEc Bond adalah dapat memudahkan siswa dalam menggambarkan bentuk ikatan yang terjadi pada suatu molekul, sehingga siswa akan lebih mudah mempelajari konsep-konsep penggambaran struktur Lewis yang dilambangkan dengan simbol dalam penjelasan materinya.

Pembelajaran menggunakan media mempunyai nilai yang baik dan peranan media pembelajaran dapat menampilkan gambaran keadaan sebenarnya sehingga siswa mampu menerjemahkan dengan baik, tidak cenderung abstrak dan verbalitas. Disinilah kemampuan berpikir kritis menjadi harapan dominannya 
pembelajaran untuk menentukan apa yang harus diyakini dan dilakukan dalam menyelesaikan suatu permasalahan (Rizky, 2014: 23). Selain itu, hasil penelitian mengenai penggunaan media pembelajaran menunjukkan bahwa dengan menggunakan media pembelajaran dapat meningkatkan hasil belajar siswa. Hasil belajar siswa dapat meningkat apabila disertai dengan proses pembelajaran yang lebih baik (Izzudin, 2013: 13).

\section{Metode Penelitian}

\section{Jenis Penelitian}

Penelitian yang dilakukan merupakan penelitian kuasi eksperimen dengan menggunakan desain penelitian Nonequivalent Control Group Design.

\section{Waktu dan Tempat Penelitian}

Penelitian ini dilaksanakan di SMA N 5 Yogyakarta pada kelas X MIPA semester gasal tahun ajaran 2017/2018. Waktu penelitian mulai dilaksanakan dari bulan Oktober sampai November 2017.

\section{Populasi dan Sampel}

Populasi terdiri dari seluruh kelas $\mathrm{X}$ MIPA berjumlah 165 siswa. Sampel yang digunakan yaitu kelas X MIPA 6 (kelas eksperimen) dan kelas $\mathrm{X}$ MIPA 3 (kelas kontrol). Sampel diambil dengan teknik simple random sampling.

\section{Teknik Pengumpulan Data}

Teknik pengumpulan data dilakukan dengan cara wawancara, dokumentasi, tes tertulis untuk mengetahui hasil belajar kognitif, observasi, dan angket untuk mengetahui keterampilan berpikir kritis siswa.

\section{Teknik Analisis Data}

Teknik analisis data yang digunakan adalah teknis analisis uji t pada analisis skor keterampilan berpikir kritis dan teknis analisis uji Mann Whitney pada analisis skor hasil belajar siswa kelas eksperimen dan kelas kontrol, serta analisis data kuantitatif untuk lembar observasi dan lembar angket. Pada penelitian ini dilakukan juga analisis tahapan keterampilan berpikir kritis siswa meliputi klarifikasi, asesmen, inferensi, dan strategi.

\section{Hasil Penelitian dan Pembahasan}

Hasil Penelitian
Data penelitian yang diperoleh berupa data tes keterampilan berpikir kritis, lembar observasi, lembar angket, dan data hasil belajar siswa.

\section{Data Tes Keterampilan Berpikir Kritis Siswa}

Data tes keterampilan berpikir kritis siswa diperoleh dari total skor siswa dibandingkan dengan total skor ideal pada masing-masing tahapan. Kemudian hasil tes keterampilan berpikir kritis dikelompokkan berdasarkan tingkat keterampilan berpikir kritis yang dapat dilihat pada Gambar 1.

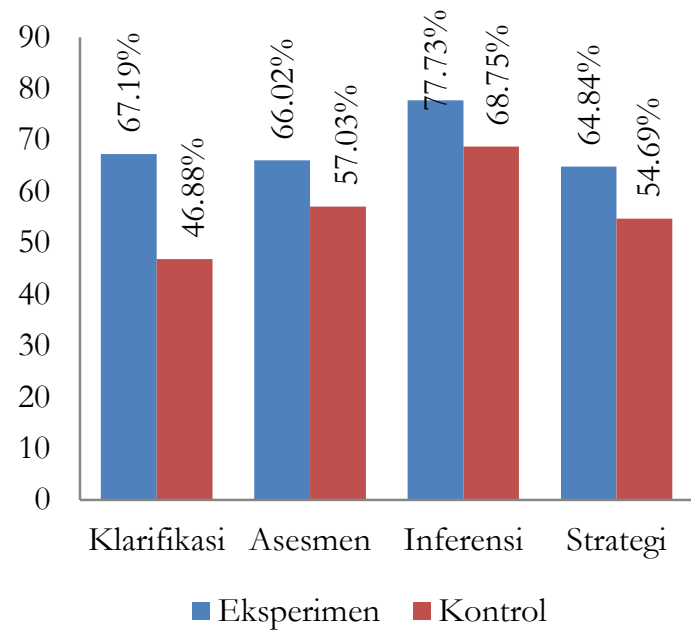

Gambar 1. Hasil Tes Keterampilan Berpikir Kritis

Selanjutnya dilakukan analisis uji statistik parametrik yaitu uji independent sample t-test. Pengujian dilakukan menggunakan program SPSS 16.0. Uji t dilakukan apabila data tes keterampilan berpikir kritis siswa sudah memenuhi uji prasyarat yang meliputi uji homogenitas dan uji normalitas. Berikut hasil uji t data tes keterampilan berpikir kritis siswa yang dapat dilihat pada Tabel 1.

Tabel 1. Hasil Uji t Data Tes

Keterampilan berpikir Kritis

\begin{tabular}{|c|c|c|c|}
\hline \multirow{2}{*}{$\begin{array}{c}\text { Equal } \\
\text { Variances } \\
\text { Variable }\end{array}$} & \multicolumn{3}{|c|}{$\begin{array}{c}\text { T-test for Equality of } \\
\text { Means } \\
\end{array}$} \\
\hline & $T$ & df & $\begin{array}{l}\text { Sig.(2- } \\
\text { tailed })\end{array}$ \\
\hline Assumed & 3,573 & 62 & 0,001 \\
\hline $\begin{array}{c}\text { Not } \\
\text { Assumed }\end{array}$ & 3,573 & 60,415 & 0,001 \\
\hline
\end{tabular}


Berdasarkan Tabel 1 diperoleh nilai sig (2-tailed) $<0,05$ maka $\mathrm{H}_{0}$ ditolak, artinya terdapat perbedaan rata-rata keterampilan berpikir kritis siswa kelas eksperimen dan kelas kontrol. Dengan demikian, penggunaan media pembelajaran MEc Bond berpengaruh terhadap keterampilan berpikir kritis.

\section{Data Lembar Observasi}

Analisis data lembar observasi dilakukan dengan cara menghitung skor dari seluruh aspek yang diamati pada setiap tahapan keterampilan berpikir kritis. Hasil dari perhitungan lembar observasi tahapan keterampilan berpikir kritis dapat dilihat pada Gambar 2 berikut.

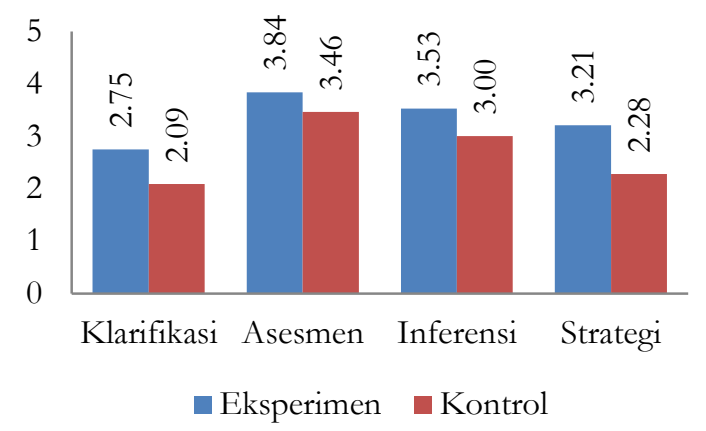

Gambar 2. Hasil Perhitungan Lembar Observasi Tahapan Kemampuan Berpikir Kritis

Berdasarkan hasil analisis skor tahapan keterampilan berpikir kritis, ratarata skor lembar observasi kelas eksperimen lebih besar daripada rata-rata skor lembar observasi kelas kontrol.

\section{Data Angket Siswa}

Analisis data lembar angket dilakukan dengan cara menghitung jumlah skor sesuai dengan aspek yang diamati. Selanjutnya, jumlah hasil skor yang diperoleh dipersentasekan dan dikategorikan sesuai dengan kualifikasi hasil angket siswa. Lembar angket ini digunakan untuk mengetahui respon siswa mengenai pengaruh media pembelajaran MEc Bond terhadap keterampilan berpikir kritis siswa setelah selesai pembelajaran.

Berdasarkan hasil penelitian yang diperoleh dari data lembar respon siswa pada kelas eksperimen, rata-rata persentase angket pada aspek pengaruh terhadap keterampilan berpikir kritis termasuk dalam kategori tinggi sebesar 80,729\%, dan aspek penggunaan media pembelajaran $\mathrm{MEc}$ Bond termasuk dalam kategori sedang sebesar 73,125\%. Hal ini menunjukkan bahwa media pembelajaran MEc Bond dapat membantu keterampilan berpikir kritis siswa dalam menyelesaikan soal.

\section{Data Hasil Belajar Kognitif Siswa}

Data hasil belajar kognitif siswa diperoleh dari skor pretest dan posttest. Hasil rata-rata skor pretest dan posttest yang ada di kelas eksperimen dan kelas kontrol dapat dilihat pada Tabel 2.

Tabel 2. Data Hasil Rata-rata Skor Tes

\begin{tabular}{lcc}
\hline \multicolumn{1}{c}{ Kelas } & Pretest & Posttest \\
\hline Eksperimen & 20,83 & 78,95 \\
Kontrol & 18,54 & 75,83 \\
\hline
\end{tabular}

Data hasil belajar siswa dilakukan analisis dengan uji statistik nonparametrik yaitu uji Mann Whitney menggunakan program SPSS 16.0. Pengujian dilakukan karena data yang dihasilkan tidak berdistribusi normal. Hasil uji Mann Whitney skor pretest dan posttest tercantum dalam Tabel 3.

Tabel 3. Hasil Uji Mann Whitney Data Hasil Belajar Siswa

\begin{tabular}{ccc}
\hline Variabel & $\begin{array}{c}\text { Asymp.sig (2- } \\
\text { tailed) }\end{array}$ & $\boldsymbol{\alpha}$ \\
\hline Pretest & 0,423 & 0,05 \\
Posttest & 0,338 & 0,05 \\
\hline
\end{tabular}

Berdasarkan tabel hasil uji Mann Whitney dari skor pretest menunjukkan bahwa kemampuan awal antara kelas eksperimen dan kelas kontrol tidak memiliki perbedaan yang signifikan, sehingga kemampuan awal siswa yang berada di kelas eksperimen maupun kelas kontrol adalah sama. Hal ini terlihat dari nilai sig.(2-tailed) yang lebih besar dari taraf signifikansi 0,05 yaitu 0,423.

Hasil uji Mann Whitney pada data posttest diperoleh nilai sig (2-tailed) 0,338 $>0,05$, sehingga $\mathrm{H}_{0}$ diterima yang berarti tidak ada perbedaan antara kelas eksperimen dan kelas kontrol. Hal ini menunjukkan bahwa tidak ada perbedaan yang signifikan hasil posttest yang 
diperoleh antara kelas eksperimen dan kelas kontrol, sehingga penggunaan media pembelajaran MEc Bond tidak berpengaruh terhadap hasil belajar siswa.

\section{Pembahasan}

1. Kajian Pengaruh Media Pembelajaran MEc Bond terhadap Keterampilan Berpikir Kritis Siswa

Keterampilan berpikir kritis yang dimaksud adalah keterampilan dimana siswa mampu menentukan konsep yang digunakan dalam penyelesaian masalah, membuat kesimpulan dengan mempertimbangkan hasil analisa, memberikan argumen secara sederhana sesuai dengan konsep materi, merumuskan suatu tindakan (strategi dan taktik) dalam penyelesaian masalah, dan mengevaluasi hasil atau keputusan yang telah diambil dalam menyelesaikan masalah dengan mengacu pada tahapan proses berpikir kritis siswa dalam menjawab soal. Tes keterampilan berpikir kritis diberikan setelah siswa mempelajari materi struktur Lewis dengan menggunakan media pembelajaran MEc Bond. Media MEc Bond berperan untuk membantu siswa dalam mengkongkretkan materi struktur Lewis yang abstrak sehingga diharapkan dapat merangsang keterampilan berpikir kritis siswa.
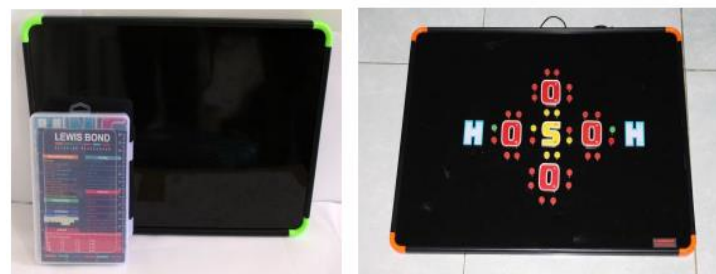

Gambar 3. MEc Bond dari Akrilik

\begin{abstract}
Adapun analisis secara deskriptif data persentase setiap tahapan keterampilan berpikir kritis yang muncul selama proses pembelajaran sebagai berikut.
\end{abstract}

a. Tahapan klarifikasi adalah tahapan dimana siswa dapat menyebutkan informasi-informasi yang dibutuhkan untuk menjawab soal. Tahapan klarifikasi pada kelas eksperimen diperoleh data sebesar $67,19 \%$ dengan kategori sedang, sedangkan pada kelas kontrol diperoleh data sebesar $46,88 \%$ dengan kategori rendah. Hal ini menunjukkan bahwa rata-rata siswa kelas eksperimen lebih mampu menyebutkan informasi-informasi yang diketahui dan pertanyaan yang diminta dalam soal dengan tepat dan dan jelas. Menurut Schoenfeld (1992) menjelaskan bahwa ketika siswa dapat memahami suatu masalah, maka secara tidak langsung siswa tersebut dapat mengkategorikan apa yang diketahui dan yang ditanyakan dalam soal. Kemampuan untuk membedakan antara yang diketahui dan tidak diketahui merupakan hal penting yang dibutuhkan siswa untuk mencapai keberhasilan dalam semua proses pembelajaran (Tobias \& Everson, 2002)

b. Tahapan asesmen adalah tahapan dimana siswa dapat menentukan konsep materi yang benar dalam menjawab soal. Tahapan asesmen pada kelas eksperimen diperoleh sebesar 66,02\% dengan kategori sedang, sedangkan pada kelas kontrol diperoleh sebesar $57,03 \%$ dengan kategori rendah. Hal ini menunjukkan bahwa rata-rata siswa kelas eksperimen lebih mampu dalam menentukan konsep materi yang benar untuk menjawab soal. Selain itu, siswa juga dapat memilah informasi yang dibutuhkan dari soal untuk menjawab pertanyaan. Siswa dapat menggunakan informasi-informasi yang relevan dalam soal serta dapat menjelaskan hubungan tiap informasi yang ada. Pada tahap asesmen siswa dapat menggunakan pernyataan yang penting dan relevan sebagai awal penyelesaian masalah (Jacob \& Sam, 2008). Siswa yang dapat mencari informasi yang relevan serta mengetahui bagaimana cara mengolah informasi yang diperoleh tersebut untuk memecahkan masalah dapat dikatakan siswa tersebut memiliki kemampuan berpikir kritis (Wijaya, 2010).

c. Tahapan inferensi adalah tahapan dimana siswa dapat membuat kesimpulan berdasarkan informasi yang telah diperoleh. Tahapan inferensi pada kelas eksperimen diperoleh data sebesar $77,73 \%$ dengan kategori tinggi, sedangkan pada kelas kontrol diperoleh data sebesar $68,75 \%$ 
dengan kategori sedang. Tingginya persentase pada kelas eksperimen menunjukkan bahwa rata-rata siswa kelas eksperimen lebih mampu dalam menemukan langkah untuk menyelesaikan soal kemudian membuat kesimpulan berdasarkan informasi yang telah diperoleh. Hal ini sesuai dengan pendapat Jacob dan Sam (2008) yang menyatakan bahwa tahap inferensi berupa tahap dimana siswa dapat membuat kesimpulan yang benar berdasarkan informasi yang telah diperoleh.

d. Tahapan strategi adalah tahapan dimana siswa dapat menjelaskan dengan baik langkah penyelesaian yang sudah ia temukan. Tahapan strategi pada kelas eksperimen diperoleh sebesar $64,84 \%$ dengan kategori sedang, sedangkan pada kelas kontrol diperoleh sebesar $54,69 \%$ dengan kategori rendah. Hal ini menunjukkan bahwa penggunaan media pembelajaran $M E c$ Bond di kelas eksperimen dapat meningkatkan keterampilan berpikir kritis siswa dalam menjelaskan langkah penyelesaian soal yang sudah ia temukan. Selain itu, siswa juga dapat mengevaluasi penyelesaian suatu permasalahan dengan benar dan dapat menyebutkan alasan yang logis dalam memilih jawaban tersebut.

Selain menggunakan data penilaian tes, digunakan pula data penilaian nontes berupa lembar observasi dan lembar angket untuk mendukung hasil penelitian tersebut. Berdasarkan hasil analisis skor tahapan keterampilan berpikir kritis, menunjukkan bahwa penggunaan media pembelajaran $M E c$ Bond di kelas eksperimen berpengaruh terhadap keterampilan berpikir kritis siswa. Siswa dapat lebih memahami konsep materi struktur Lewis dengan jelas, sehingga pada saat siswa diberikan suatu soal untuk mengasah keterampilan berpikir kritis, maka siswa dapat menjelaskan langkah penyelesaian dengan benar.

Pembelajaran yang diterapkan di kelas kontrol menggunakan alat peraga berupa media pembelajaran kancing yaitu menggunakan kancing dengan ukuran dan warna yang berbeda-beda. Kancing dengan ukuran dan warna tertentu mewakili unsur dan kancing dengan ukuran kecil mewakili elektron valensinya.

Pembelajaran menggunakan media pembelajaran kancing menunjukkan sebagian siswa merasa tidak bersemangat dan tidak terlalu aktif karena media pembelajaran kancing yang digunakan tidak begitu menarik bagi mereka. Sebagian anak merasa bingung karena kancing yang digunakan tidak mewakili bentuk huruf suatu unsur. Lain halnya dengan kelas eksperimen, mereka terlihat bersemangat dan aktif dalam mencoba media pembelajaran $M E c$ Bond dikarenakan bentuknya yang menarik dan lebih konkret, sehingga dapat membantu siswa dalam memahami materi struktur Lewis.

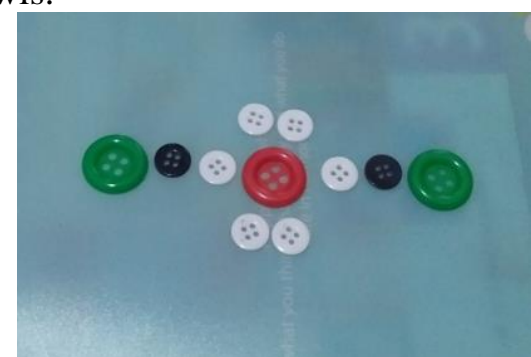

Gambar 4. Media Pembelajaran Kancing

Selain lembar observasi, hasil penelitian didukung pula dengan analisis hasil lembar angket yang diberikan kepada siswa di kelas eksperimen. Hasil rata-rata persentase angket menunjukkan bahwa aspek pengaruh terhadap keterampilan berpikir kritis termasuk dalam kategori tinggi, sedangkan aspek penggunaan media pembelajaran $M E c$ Bond termasuk dalam kategori sedang. Hal ini menunjukkan bahwa media pembelajaran $M E c$ Bond dapat membantu keterampilan berpikir kritis siswa dalam menyelesaikan soal. Jadi, dapat disimpulkan dari ketiga instrumen penelitian yang dilakukan mendukung adanya pengaruh media pembelajaran $M E c$ Bond terhadap keterampilan berpikir kritis siswa.

2. Kajian Pengaruh Media Pembelajaran MEc Bond terhadap Hasil Belajar Siswa

Proses pembelajaran pada kelas eksperimen dan kelas kontrol diberikan perlakuan yang berbeda dalam jenis media yang digunakan. Kelas eksperimen menggunakan media pembelajaran $M E c$ Bond, sedangkan kelas kontrol menggunakan media pembelajaran 
kancing. Proses pembelajaran pada kelas eksperimen dan kelas kontrol dilakukan masing-masing sebanyak empat kali pertemuan.

Kelebihan menggunakan media pembelajaran $M E c$ Bond yaitu mampu meningkatkan hasil belajar dan mengembangkan keterampilan berpikir kritis dalam mengeksplor gagasan serta pendapatnya dengan melihat secara jelas dari proses pembentukan ikatan kimia menggunakan struktur Lewis. Siswa diharapkan dapat memahami materi yang telah dipelajari dan merasa senang dengan pembelajaran yang telah berlangsung. Pembelajaran menggunakan media pembelajaran $M E c$ Bond dapat berjalan lancar dan siswa ikut berpartisipasi aktif dalam kegiatan belajar mengajar di kelas.

Proses pembelajaran di kelas kontrol menggunakan media pembelajaran kancing. Alasan pemilihan media kancing dikarenakan media tersebut pernah digunakan di salah satu SMA/MA sebagai media pembelajaran pada materi pokok struktur Lewis. Selain itu, media pembelajaran kancing dalam penelitian ini digunakan sebagai salah satu alternatif untuk menyetarakan media pembelajaran yang digunakan di kelas eksperimen. Media pembelajaran kancing diharapkan dapat mewakili gambaran proses pembentukan ikatan kimia menggunakan struktur Lewis. Namun, terdapat kekurangan selama proses pembelajaran berlangsung yaitu sebagian siswa tidak merasa tertarik dengan media yang digunakan, sehingga mereka lebih memilih mengerjakan dengan cara menuliskan struktur Lewis di buku. Selama proses pembelajaran, semua siswa baik kelas eksperimen maupun kelas kontrol juga menggunakan LKS (Lembar Kerja Siswa) dan handout sebagai salah satu sumber belajar bacaan siswa.

Berdasarkan uji statistika, hasil belajar siswa menunjukkan tidak ada perbedaan yang signifikan antara kelas eksperimen dan kelas kontrol, sehingga penggunaan media pembelajaran $M E c$ Bond tidak berpengaruh terhadap hasil belajar siswa. Meskipun demikian, baik kelas eksperimen maupun kelas kontrol menunjukkan hasil belajar siswa di atas rata-rata KKM 70.
Tidak adanya pengaruh penggunaan media pembelajaran $M E c$ Bond terhadap hasil belajar siswa disebabkan oleh faktor penyajian soal yang apabila dilihat dari tingkat kesukarannya masih tergolong mudah dan sedang, sehingga tidak ada perbedaan yang signifikan antara hasil belajar kelas eksperimen dan kelas kontrol. Selain itu, dengan menggunakan soal pilihan ganda, peluang kerjasama antar siswa sangat besar, dan apabila siswa tidak mengetahui jawaban, mereka akan cenderung menerka jawaban yang kira-kira menurutnya benar. Hal ini mengakibatkan guru sulit mengukur kemampuan hasil belajar siswa.

\section{Simpulan}

Berdasarkan hasil penelitian dan pembahasan di atas, diperoleh beberapa kesimpulan sebagai berikut:

1. Penggunaan media pembelajaran $M E c$ Bond berpengaruh terhadap keterampilan berpikir kritis siswa. Hal ini dibuktikan dengan nilai sig (2-tailed) dari uji independent sample t-test lebih kecil dari 0,05 sehingga $\mathrm{H}_{0}$ ditolak, artinya terdapat perbedaan rata-rata keterampilan berpikir kritis siswa kelas eksperimen dan kelas kontrol.

2. Penggunaan media pembelajaran $M E c$ Bond tidak berpengaruh terhadap hasil belajar siswa. Hal ini dibuktikan dengan nilai sig (2-tailed) dari uji Mann Whitney lebih besar dari 0,05 sehingga $\mathrm{H}_{0}$ diterima yang berarti tidak ada perbedaan yang signifikan antara kelas eksperimen dan kelas kontrol. Meskipun demikian, baik kelas eksperimen maupun kelas kontrol menunjukkan hasil belajar siswa di atas rata-rata KKM 70.

\section{Ucapan Terima Kasih}

Terimakasih disampaikan kepada kedua orang tua dan keluarga serta almamater tercinta Program Studi Pendidikan Kimia Fakultas Sains dan Teknologi UIN Sunan Kalijaga Yogyakarta.

\section{Daftar Pustaka}

Denny, P. L. \&Lestari, W. (2017). Kemampuan berpikir kritis siswa dalam 
menyelesaikan soal performance task. Seminar Matematika dan Pendidikan Matematika UNY, tanggal 11 November 2017. Yogyakarta: Universitas Negeri Yogyakarta.

Haris, M.\& Loka. (2013). Pengembangan perangkat pembelajaran kimia dengan model pembelajaran kooperatif terpadu numbered head together dan two stay two stray dalam upaya mengatasi kesulitan belajar siswa kelas X SMA memahami konsep-konsep kimia. Jurnal Pijar MIPA, 9(1), 26-31.

Hayat, B., \& Suhendra Y. (2010). Benchmark internasional: Mutu pendidikan. Jakarta: Bumi Aksara.

Ibrahim. (2011). Pengembangan bahan ajar matematika sekolah berbasis masalah terbuka untuk memfasilitasi pencapaian kemampuan berpikir kritis dan kreatif matematis siswa. Seminar Matematika dan Pendidikan Matematika, tanggal 3 Desember 2011. Yogyakarta: Univesitas Negeri Yogyakarta.

Izzudin, A.M. (2013). Efektivitas penggunaan media pembelajaran video interaktif untuk meningkatkan hasil belajar praktik service engine dan komponenkomponennya. Skripsi, tidak dipublikasikan. Universitas Negeri Semarang.

Jacob, S. M., \& Sam, H. K. (2008). Measuring critical thinking in problem solving through online discussion forums in first year, University Mathematics.

Kemendikbud. (2016). Peringkat dan Capaian Pisa Indonesia. https://www.kemdikbud.go.id/main/blo g/2016/12/peringkat-dan-capaian-pisa indonesia-mengalami-peningkatan. Jakarta: Biro Komunikasi dan Layanan Masyarakat Kementerian Pendidikan dan Kebudayaan.

Kurniawati, W. Y. (2013). Pengembangan alat peraga dan lembar kerja siswa berorientasi konstruktivisme dalam pembelajaran kimia SMA. Prosiding Semirata FMIPA Universitas Lampung, tanggal 10-13 Mei 2013. Lampung: Universitas Lampung.
Lubezky, A., Dori, Y. J., \& Zoller, U. (2004). HOCS-promoting assessment of students' performance on environmentrelated undergraduate chemistry.Chemistry education research and practice, 5(2), 175-184.

Mahyudin. (2007). Pembelajaran asam basa dengan pendekatan kontekstual untuk meningkatkan literasi sains siswa SMA.Tesis, tidak dipublikasikan. Pascasarjana UPI.

Rizky, I. (2014). Analisis keterampilan berpikir kritis siswa dengan menggunakan media pembelajaran (video) pada materi minyak bumi.Skripsi, tidak dipublikasikan. UIN Syarif Hidayatullah.

Schoenfeld. A.H. (1992). Learning to think mathematically: Problem solving, metacognition, and sense makin in mathematics. New York: Macmillan Publishing Company.

Tobias, S. \& Everson, H. (2002). Knowing what you know and what you don't further research on metacognitive knowledge monitoring. New York: College Board.

Widyaningtyas R., Kusumah, Y.S., Sumarno, U., \& Sabandar, J. (2015). The impact of problem based learning approach to senior high school students' mathematics critical thinking ability. Journal on Mathematics Education, 6 (2), 30 - 38 